\title{
A consumer perspective of the South African red meat classification system
}

\author{
H. Vermeulen ${ }^{1,2 \#}$, H.C. Schönfeldt ${ }^{2,3}$ \& B. Pretorius ${ }^{2,3}$ \\ ${ }^{1}$ Bureau for Food and Agricultural Policy (BFAP), Pretoria, South Africa \\ ${ }^{2}$ Department of Animal and Wildlife Sciences, University of Pretoria, Pretoria, South Africa \\ ${ }^{3}$ Institute of Food, Nutrition and Well-being, University of Pretoria, Pretoria, South Africa
}

(Received 10 September 2014; Accepted 10 April 2015; First published online 11 August 2015)

Copyright resides with the authors in terms of the Creative Commons Attribution 2.5 South African Licence. See: http://creativecommons.org/licenses/by/2.5/za

Condition of use: The user may copy, distribute transmit and adapt the work, but must recognise the authors and the South African Journal of Animal Science.

\begin{abstract}
The South African consumer market is characterised by socio-economic and cultural diversity. Food expenditure patterns, behaviour and preferences differ significantly between the various socio-economic subgroups. Packaging information, including red meat classification information, could be an important tangible resource used by consumers to gauge product quality. The first objective of the research reported in this paper is to investigate the red meat knowledge, usage and perceptions regarding beef and sheep meat classification and related quality parameters among South African consumers. Consumer perceptions of red meat classification were extracted from a comprehensive consumer survey among stratified representative samples of South African low-, middle- and high-income consumers $(n=165, n=171$ and $n=249)$. The paper also briefly reports on an in-store 'observational' research project that was conducted to develop an understanding of the communication of carcass classification to consumers through fresh red meat product labels at independent butchers and large retailers across South Africa $(n=60)$. Low-income consumers had very limited understanding and gave little attention to red meat classification. Even though middle-class and wealthy consumers also have a limited understanding of red meat classification, about half of these consumers check for a classification mark. Red meat classification was not mentioned by consumers as a major concern regarding red meat, but related aspects were important such as quality, fattiness, tenderness, juiciness, taste, freshness, smell and appearance. Purchase considerations for beef and mutton/lamb focussed largely on safety, appearance, price and eating quality. Labelling information observed at retail outlets gave very little attention to classification. There is a definite need for consumer education relating to the red meat classification system and for the development of an appropriate front-of-pack labelling system to communicate red meat classification.
\end{abstract}

Keywords: Beef, high-income, knowledge, labelling information, lamb, low-income, middle-income, mutton, perceptions

\#Corresponding author: hester@bfap.co.za

\section{Introduction}

The South African Carcass Classification System classifies lamb, mutton, beef and goat carcasses based on a set of predefined characteristics mainly focusing on animal age and the fat content of the carcass. The type of production system (i.e. grain-fed versus grass-fed animals) is to some extend embedded in the classification criteria. This system has been in use since June 1992 (Agricultural Product Standards Act, 1990 (Act No.119 of 1990)). Carcass class is indicated on the carcass by means of a coloured roller mark stamp. After processing into retail cuts only some cuts will display the roller mark (Healthy Meat South Africa, 2012).

Even though the system plays an important role in classifying red meat carcasses to facilitate carcass price formation, it should play a role at the consumer interface. Various classes within the carcass classification system imply different product characteristics which should enable consumers to make decisions about desirable product options.

The South African consumer market is characterised by socio-economic and cultural diversity. Various tools exist to classify consumers within this socio-economic spectrum. The income and expenditure deciles applied by Statistics South Africa (StatsSA) for their Income and Expenditure Surveys (StatsSA, 2012a) each represent $10 \%$ of the population from an income or expenditure point of view. Another widely used tool which 
will be discussed in this paper in more detail is the Living Standards Measure (LSM ${ }^{\circledR}$ ) market segments developed and maintained by the South African Audience Research Foundation (SAARF). Socio-economic status increases with increasing LSM $^{\circledR}$ level (SAARF, 2013).

Various lifestyle levels can be identified across the $\mathrm{LSM}^{\circledR}$ spectrum. For example, one approach is to distinguish between marginalised/poor consumers $\left(\mathrm{LSM}^{\circledR} 1-4\right)$, the middle-class $\left(\mathrm{LSM}^{\circledast} 5-8\right)$ and wealthy consumers $\left(\right.$ LSM $\left.^{\circledast} 9-10\right)$. In general the SAARF LSM ${ }^{\circledast}$ segments are not directly based on the income levels of consumers, but are based on consumer access to various amenities, such as durables, household location and dwelling type. Table 1 presents a summary of the characteristics of these lifestyle levels.

Table 1 Overview of the three main lifestyle levels within the 10 Living Standards Measure $\left(\mathrm{LSM}^{\circledR}\right)$ segments (Sources: BFAP 2014, based on data from SAARF All Media and Product Survey (AMPS ${ }^{\circledR}$ ) 2013; StatsSA 2012a)

\begin{tabular}{|c|c|c|c|}
\hline & Marginalised/poor group & Middle-class & Wealthy consumers \\
\hline LSM $^{(\otimes)}$ segments & $\operatorname{LSM}^{(B)} 1-4$ & $\operatorname{LSM}^{(8)} 5-8$ & $\operatorname{LSM}^{(B)} 9-10$ \\
\hline $\begin{array}{l}\text { Share of SA adult population (15 } \\
\text { years+) }\end{array}$ & $22.3 \%$ & $61.2 \%$ & $16.5 \%$ \\
\hline $\begin{array}{l}\text { Average household monthly } \\
\text { income (self-reported) }\end{array}$ & R1480 to R3205 & R4344 to R16754 & R23539 to R36883 \\
\hline $\begin{array}{l}\text { Estimated contribution to total } \\
\text { purchasing power in South } \\
\text { Africa }\end{array}$ & $\pm 5 \%$ & $\pm 50 \%$ & $\pm 40 \%$ to $50 \%$ \\
\hline $\begin{array}{l}\text { Estimated share of total } \\
\text { expenditure allocated to food } \\
\text { and non-alcoholic beverages }\end{array}$ & $35 \%$ to $34 \%$ & $32 \%$ to $15 \%$ & $10 \%$ to $6 \%$ \\
\hline Dominant education level & $\begin{array}{l}\text { Up to primary completed } \\
\text { Some high schooling }\end{array}$ & $\begin{array}{l}\text { Some high schooling } \\
\text { Matric }\end{array}$ & $\begin{array}{c}\text { Matric } \\
\text { Post-matric qualification }\end{array}$ \\
\hline Dominant age groups & $15-24$ and $50+$ & $15-49$ & $35+$ \\
\hline Dominant location (rural/urban) & Mostly rural, some urban & Increasingly urban & Urban \\
\hline Dominant provincial location & $\begin{array}{l}\text { KwaZulu-Natal, Eastern } \\
\text { Cape, Limpopo }\end{array}$ & $\begin{array}{c}\text { KwaZulu-Natal, Gauteng, } \\
\text { Western Cape }\end{array}$ & $\begin{array}{c}\text { Gauteng, Western Cape, } \\
\text { KwaZulu-Natal }\end{array}$ \\
\hline $\begin{array}{l}\text { Unemployment rate (self- } \\
\text { reported) }\end{array}$ & $41 \%$ to $43 \%$ & $38 \%$ to $17 \%$ & Insignificant \\
\hline Dominant dwelling type & $\begin{array}{c}\text { Traditional hut, } \\
\text { house/cluster house/town } \\
\text { house }\end{array}$ & $\begin{array}{c}\text { Matchbox house, } \\
\text { house/cluster house/town } \\
\text { house, flat }\end{array}$ & $\begin{array}{c}\text { House/cluster house/town } \\
\text { house, flat }\end{array}$ \\
\hline $\begin{array}{l}\text { Share of group with access to } \\
\text { in-home electricity }\end{array}$ & $27 \%$ to $93 \%$ & $98 \%$ to $100 \%$ & $100 \%$ \\
\hline $\begin{array}{l}\text { Share of group with access to } \\
\text { tap water in home or on plot }\end{array}$ & $0 \%$ to $52 \%$ & $82 \%$ to $100 \%$ & $100 \%$ \\
\hline
\end{tabular}

Class mobility is a prominent feature of the South African consumer market, where consumers move towards higher $\mathrm{LSM}^{\circledR}$ groups driven by economic growth as well as socio-economic empowerment. As is evident from Figure 1, from 2004 to 2013 the share of South African adults in SAARF LSM ${ }^{\circledR}$ segments 1 - 4 declined $(-56 \%)$, accompanied with an increase in the share of the adult population classified in wealthier segments such as LSM 7 (+99\%), LSM ${ }^{\circledR} 8(+82 \%)$, LSM $^{\circledR} 6(+69 \%)$ and LSM $^{\circledR} 9$ (+68\%). In recent years the class mobility rate has been variable. In generally increased in most of the socio-economic sub-groups after slowing down from 2007/2008 to 2009/2010 due to recession impacts (BFAP, 2014).

Food expenditure patterns differ significantly between the various LSM $^{\circledR}$ groups as illustrated in Figure 2. (as estimated from the Statistics South Africa (StatsSA) Income and Expenditure Survey 2010/11) (StatsSA, 2012a). Marginalised consumers spend the largest relative share on grain-based staple foods (32\% of their total expenditure), followed by meat products $(22 \%)$, vegetables $(11 \%)$, and dairy and eggs (8\%). The middle-class group spends relatively less of their total expenditure on grain-based staples (26\%), relatively more on meat products $(26 \%)$, followed by vegetables $(10 \%)$, as well as dairy and eggs (9\%). The wealthiest segment of the population spends only $16 \%$ of their total food expenditure on grain-based staple foods, with meat representing their main expenditure category (27\%), followed by dairy and eggs (11\%) and vegetables (9\%). 


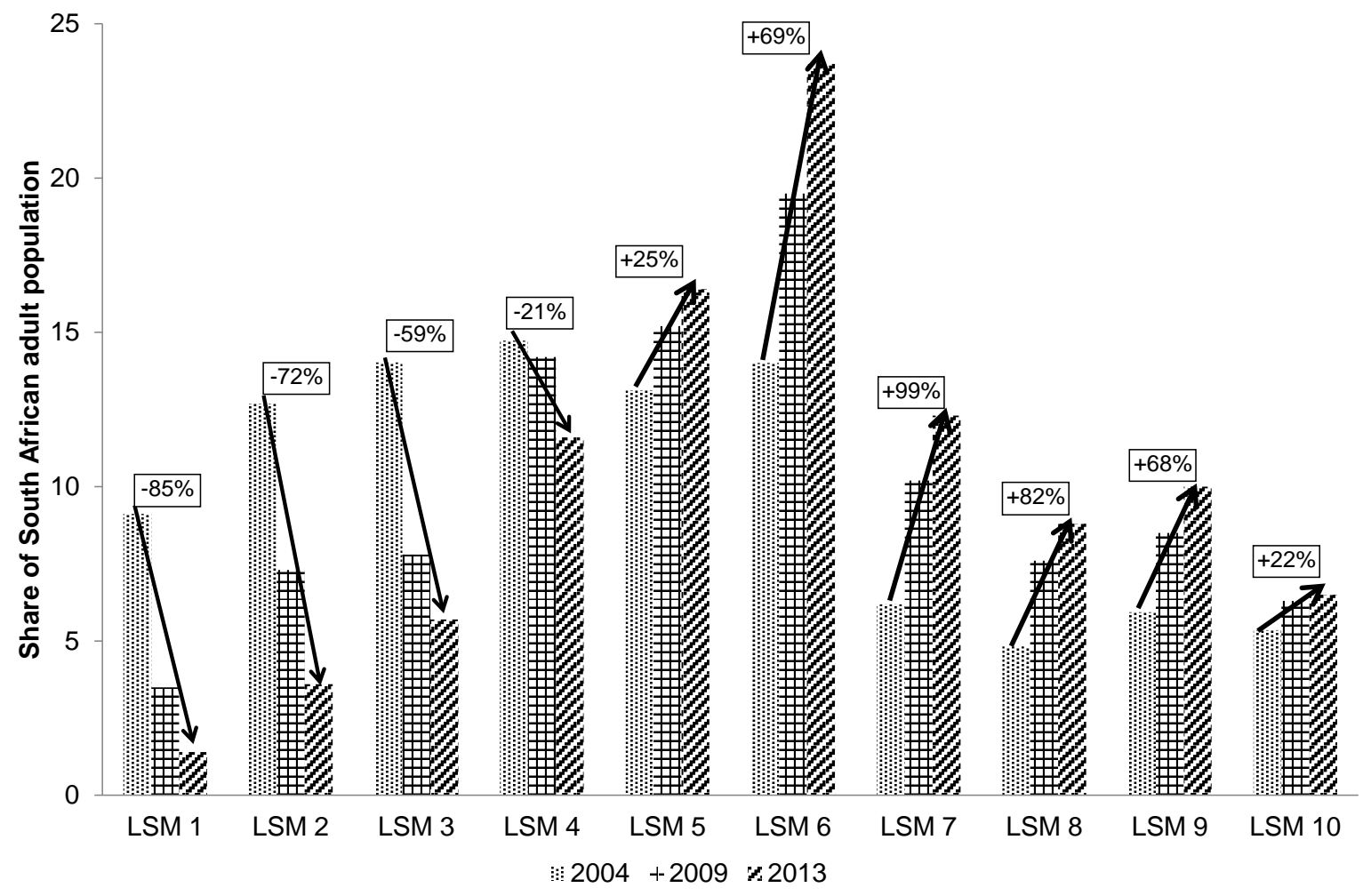

Figure 1 Class mobility among Living Standards Measure (LSM $\left.{ }^{\circledR}\right)$ segments from 2004 to 2013. (Source: BFAP 2014, based on data from SAARF AMPS ${ }^{\circledR} 2004$ to 2013).

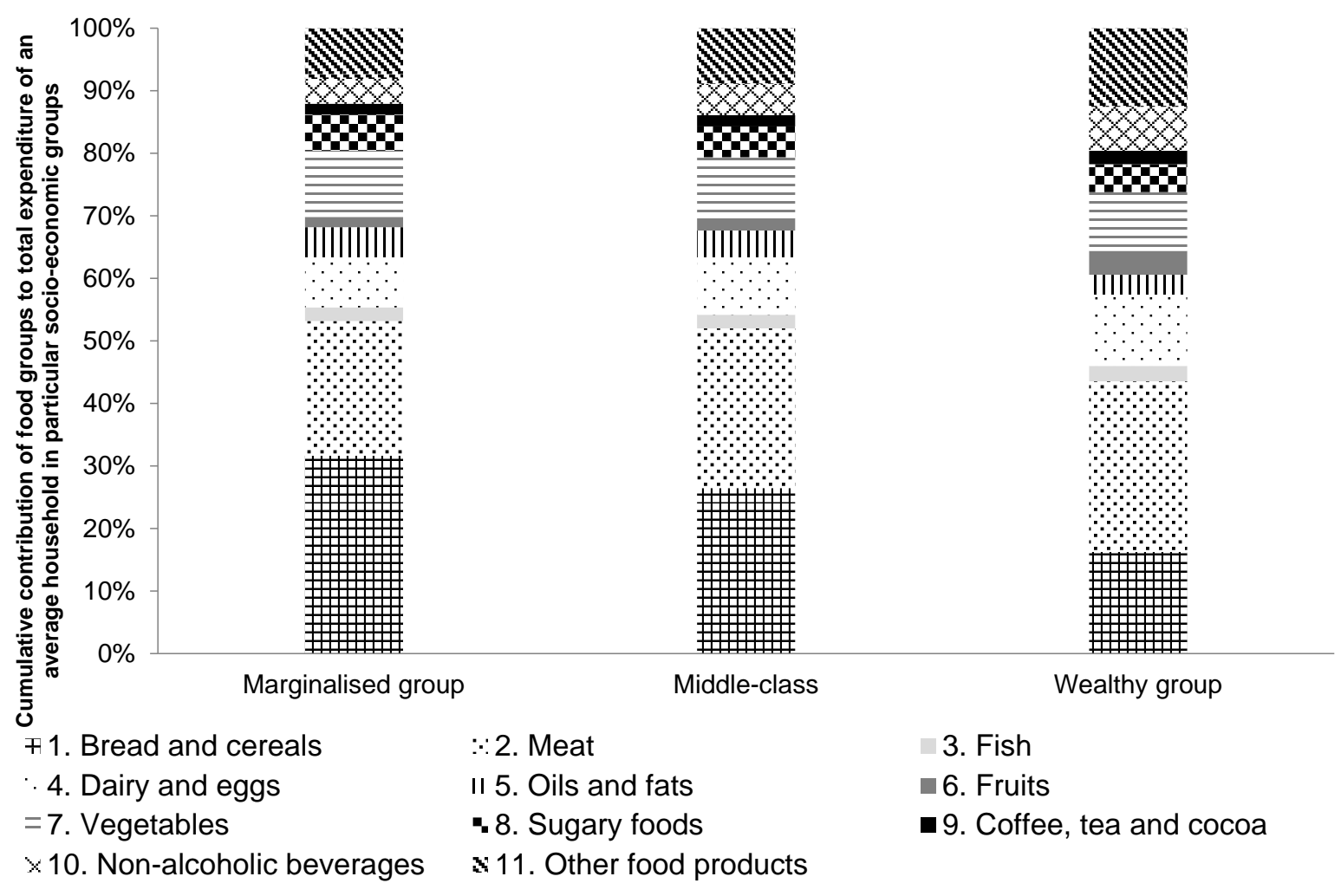

Figure 2 Estimated food expenditure composition of the main socio-economic sub-groups in South Africa. (Source: Calculations based on data obtained from Statistics South Africa Income and Expenditure Survey 2010/11) (StatsSA, 2012a). 
The meat expenditure patterns of South African consumers, estimated from the Statistics South Africa Income and Expenditure Survey 2010/11, indicate that the middle-class dominated the expenditure on poultry. The wealthy segment dominated spending on sheep meat as well as pork. The middle-class and wealthy groups both had large expenditures on beef, processed pork and beef sausage (see Figure 3). Despite consuming all meat types, the low-income consumer segment has a clear preference for chicken followed by beef, as evident from Figure 3.

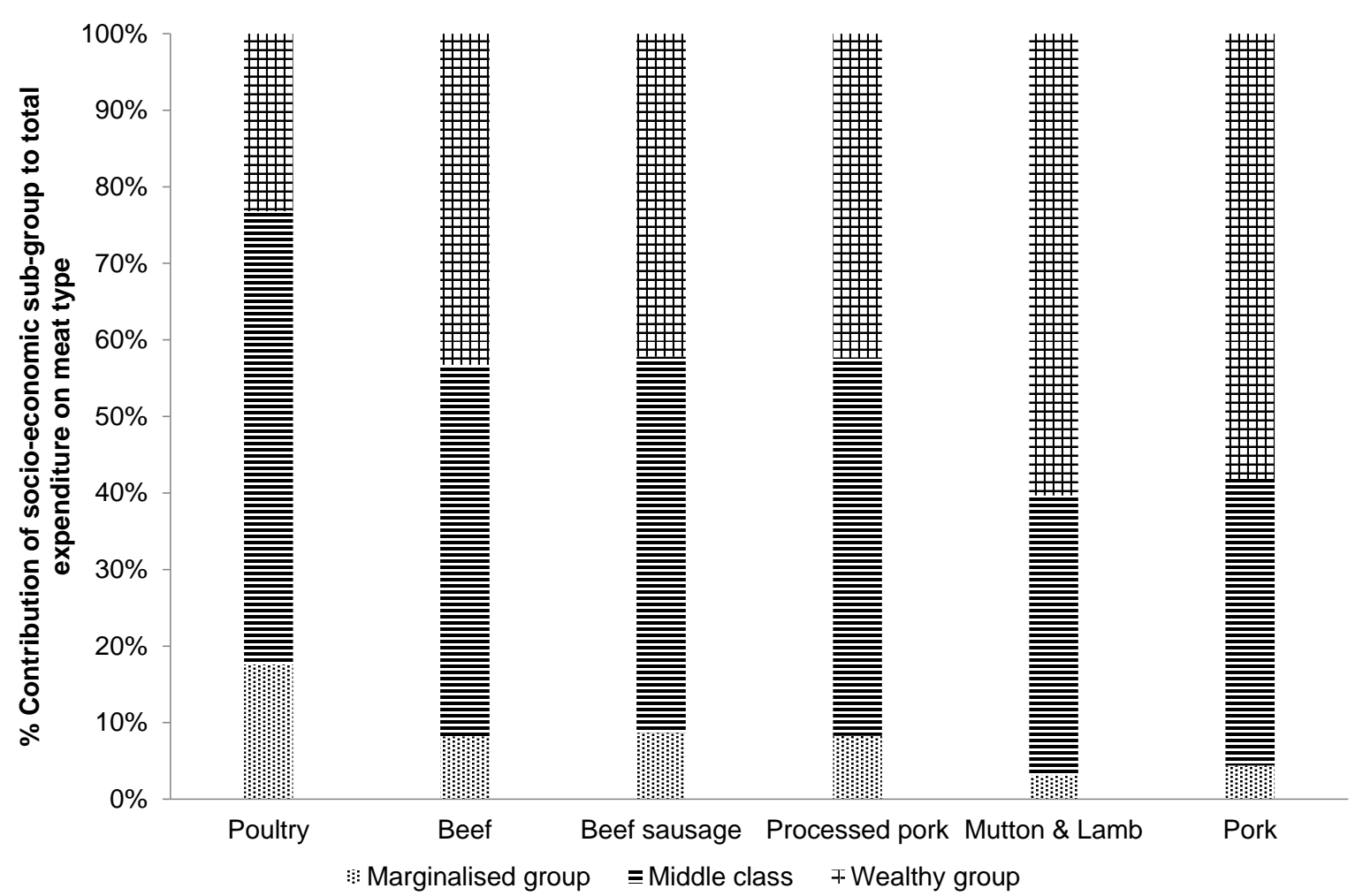

Figure 3 Meat expenditure patterns of socio-economic sub-groups in South Africa.

(Source: Calculations based on data obtained from Statistics South Africa Income and Expenditure Survey 2010/11).

Due to factors such as class mobility, urbanisation and changing preferences, the meat expenditure patterns of South African consumers are changing over time. To illustrate some of these changes, Figure 4 presents the changes in the annual expenditure of households on particular meat types after removing the effect of inflation (i.e. real changes in expenditure) (BFAP, 2014 based on data obtained from Statistics South Africa Income and Expenditure Surveys 2005/06 and 2010/11 [StatsSA, 2008; StatsSA, 2012a]). The most significant increases in real household expenditure on particular meat types, implying higher consumption levels from 2005 to 2010 were:

- Marginalised group: Processed pork (+121\% increase in household expenditure above inflation), Poultry $(+21 \%)$; Beef $(+17 \%)$, Beef sausage $(+3 \%)$;

- Middle-class group: Pork (+123\%), Processed pork (+80\%), Beef (+13\%), Poultry $(+5 \%)$;

- Wealthy group: Processed pork (+48\%), Beef sausage (+9\%), Pork $(+5 \%)$, Beef $(+5 \%)$.

The middle-class group experienced real expenditure growth in the largest number of meat categories (all except for sheep meat) from 2005 to 2010.

When purchasing products, including red meat, how consumers evaluate quality, will influence their purchasing behaviour. Quality is a complex concept with many definitions depending on perspective. Quality can be defined as the 'totality of features and characteristics of a product or service that bear on its ability to satisfy stated or implied needs' (Kotler, 2000). To classify quality characteristics in a meaningful manner, it is necessary to consider a suitable conceptual model of the quality perception process. For this purpose the model developed by Steenkamp (1989) (as applied by Oude Ophuis \& Van Trijp, 1995) are presented where a distinction is made between quality cues and quality attributes (see Figure 5 for examples of meat quality cues and attributes and Diagram 1 depicting the conceptual structure of this model). Ultimately the 
combination of environmental cues, personal factors, situational factors, quality cues and quality attributes could impact how consumers perceive the quality of the particular product.

Consumers are able to determine quality 'cues' with certainty before consumption by using their senses. 'Intrinsic quality cues' are part of the physical product and cannot be changed without changing the physical characteristics of the product itself. 'Extrinsic quality cues' are related to the product but not physically part of the product and can thus be changed without changes to the physical product.

Quality 'attributes' are product characteristics that deliver potential benefits to the consumer, but can only be observed after consumption and thus consumers generally have to rely on their perceptions of these attributes to form quality judgments prior to consumption. 'Experience quality attributes' can only be evaluated with certainty by the consumer after consumption and an actual experience of the product.

'Credence quality attributes' are 'intangible' and cannot be evaluated with certainty by the consumer even after consumption. Consequently consumers have to rely on judgment or the information of other roleplayers to develop certainty that the particular attribute is part of the particular product.

The quality cues and attributes linked to red meat classification are shown in Bold and Italic font in Table 2. Some factors are directly linked to red meat classification, such as the intrinsic quality cue 'visible fat on meat', the experience quality attributes 'fattiness of meat in terms of non-visible fat' and the intangible quality attributes of 'animal feeding practices' (in particular grass-fed versus grain-fed) and 'age of animal at time of slaughter'. The latter factor was listed as intangible as most consumers may not have the expertise to judge animal age based on the visual appearance of the meat and have to rely on product information supplied in this regard. Other factors could be linked indirectly to red meat classification in Table 2, such as meat colour, fat colour, taste, tenderness, juiciness, healthiness and nutritional value of the meat (e.g. in terms of fat content).

To utilise the South African Carcass Classification System for informed decision-making, consumers need a proper understanding of the various classes, as well as the quality attributes implied by these classes. Doubt arose in this regard, leading to a number of critical research questions. Do South African consumers across the socio-economic spectrum understand and utilise the Carcass Classification System when purchasing red meat? Do they understand the quality implications of different carcass classes? Are the quality signals (i.e. roller marks on meat and/or labelling information) in place to facilitate informed decision

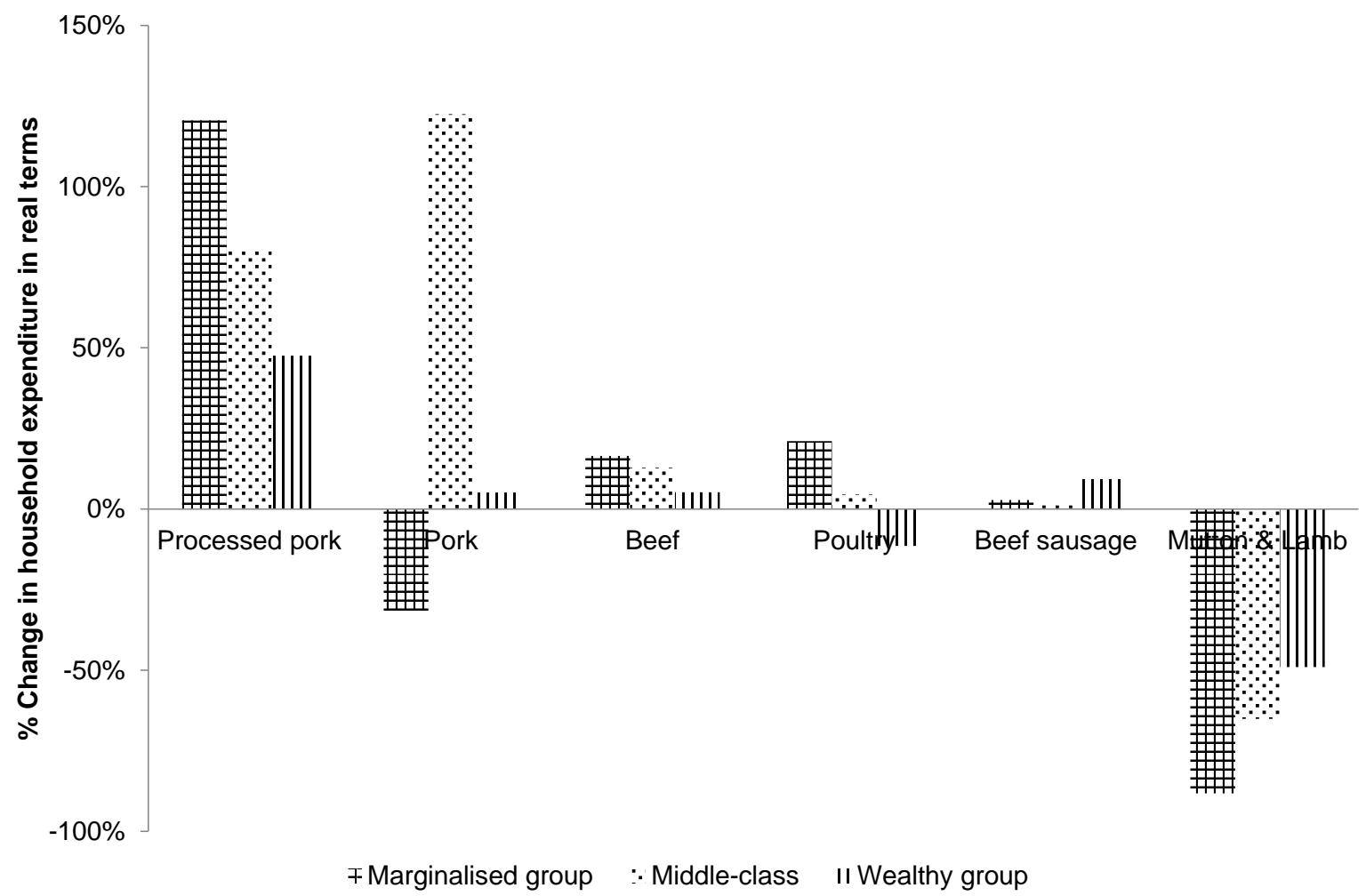

Figure 4 Real changes in the expenditure of households on main meat types by socio-economic sub-groups in South Africa 2005 and 2010.

(Source: BFAP 2014 based on data from Statistics South Africa Income and Expenditure Surveys 2005/06 and 2010/11). 
Table 2 Examples of quality cues and attributes applicable to meat (Source: Adopted from Oude Ophuis \& Van Trijp, 1995)

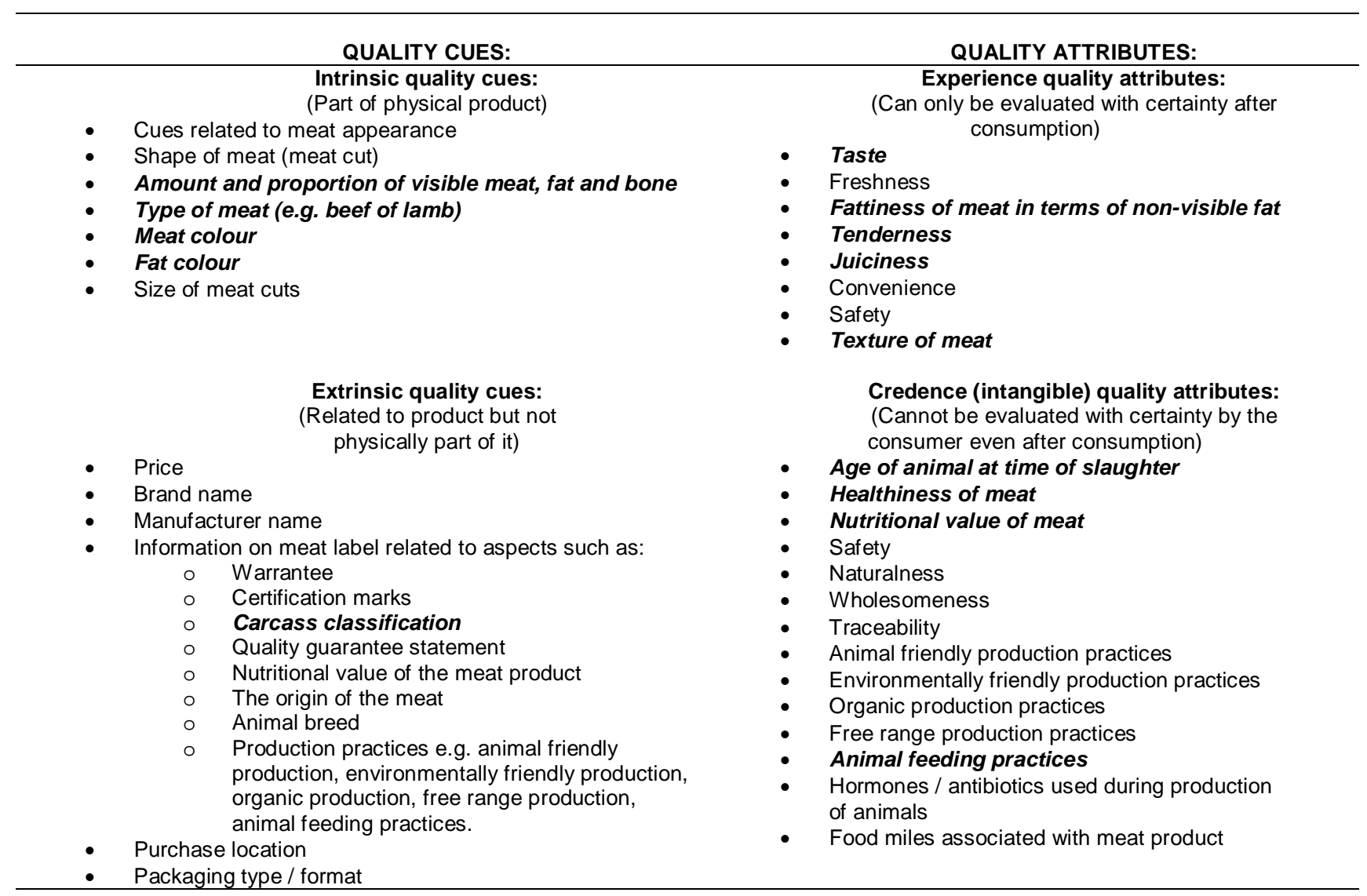

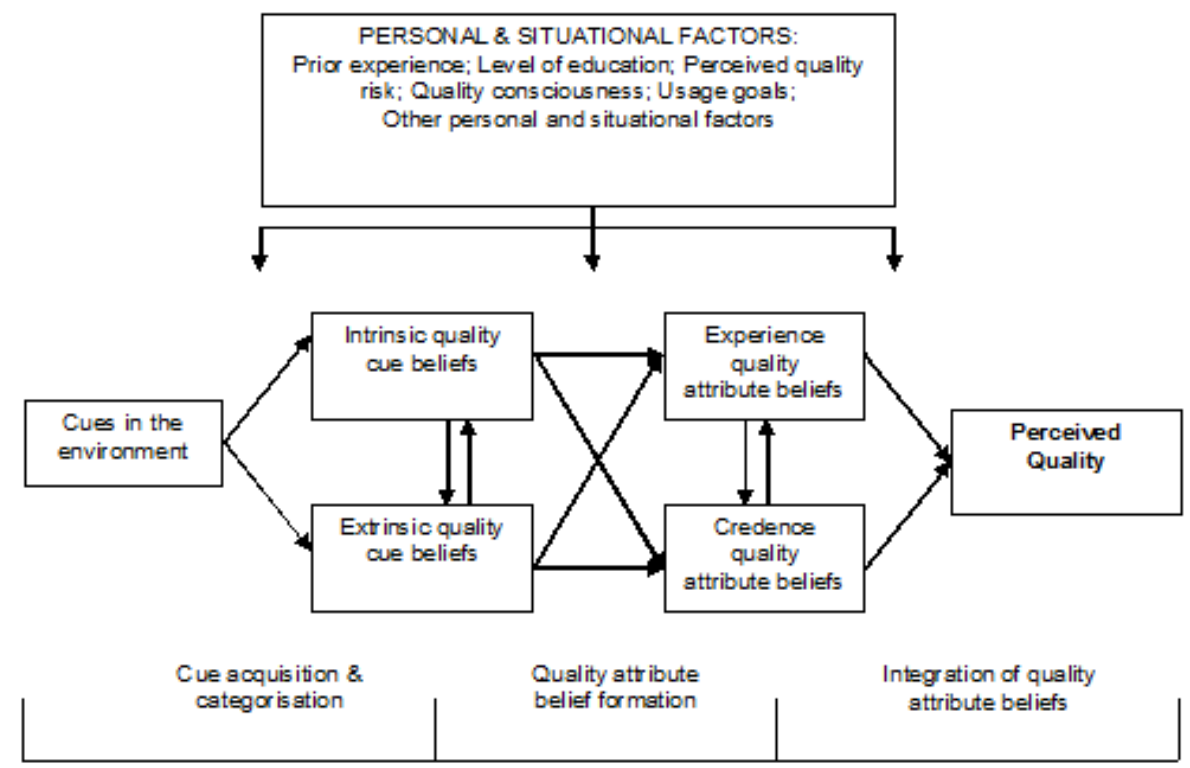

Diagram 1 Conceptual model of the quality perception process (Source: Steenkamp 1989). 
making regarding carcass classification? The last research question is of particular relevance in the light of the identity loss created when roller-marked meat is processed into individual cuts where some of these cuts will not display the roller mark.

Due to the lack of relevant scientific data the first objective of the research reported in this paper was to investigate South African red meat consumer knowledge, usage and perceptions regarding beef and sheep meat classification and related quality parameters among low-, middle- and high-income consumers. The paper also reports on an in-store observational research study that was conducted to develop an understanding of the communication of carcass classification to consumers through fresh red meat product labels.

\section{Materials and Methods}

The data reported in this paper were part of a comprehensive consumer research project conducted during 2012/2013 on behalf of the South African Red Meat Industry. The overall project objective was to investigate South African consumer behaviour towards and perceptions to red meat. Consumers were divided into three socio-economic groups: the marginalised class (low-income consumers) (LSM $\left.{ }^{\circledR} 1-4\right)$, the middle-class (middle-income consumers) $\left(\operatorname{LSM}^{\circledR}{ }^{5-8}\right.$ ) and the wealthy group (high-income consumers) $\left(\operatorname{LSM}^{\circledast}\right.$ 9-10) residing in the Gauteng Province of South Africa. The specific focus of the study was current meat purchasing and consumption behaviour, behavioural motivations and perceptions of red meat, and current and most trusted information sources relating to red meat. The survey questionnaire drew on previous questionnaires that were used to compare data (Meat Board's Quantitative Survey, 1996; Protein survey, 1996; Quantitative survey, 1997; South African Pork Producers Organisation (SAPPO), 2000). The questionnaire was also tested in a pilot study in Limpopo to validate it (De Cock et al., 2013). A wide range of question types were used including dichotomous questions, multiple choice questions, Likert scale/level of agreement, rating scale questions and open-ended questions.

The survey targeted adult consumers from both gender groups responsible for food purchasing and preparation in their households residing in the Gauteng Province of South Africa. Gauteng is the smallest province in South Africa, but generates 34\% of South Africa's Gross Domestic Product (GDP). A fifth of the South African population (11.3 million people) resides in Gauteng. It is the wealthiest and most densely populated province (City of Johannesburg, 2013). Quota sampling was applied with the sampling plan which had been designed by the research team to reflect the characteristics of the South African population in terms of LSM ${ }^{\circledR}$ segment, age category and ethnic groups $(n=165, n=171$ and $n=249$ for the low-income group, middle-class group and wealthy consumer group, respectively). No formal female/male split was included in the sampling, but it was expected that the sample would be dominated by female consumers given their traditional dominance in household food purchasing. Table 3 presents a summary of the planned and actual characteristics of the sample in terms of $\mathrm{LSM}^{\circledR}$ segment, age category, ethnicity and gender group.

This study was approved by the ethics committee of the University of Pretoria (Ethical Clearance certificate: EC 11118/072). Participants were ensured of confidentiality and encouraged to provide accurate answers.

Data gathering was done during 2012 and 2013. A typical consumer interview lasted between 90 minutes and two hours. Panel recruitment was done through a professional consumer panel recruitment agency ('Consumers in Focus'), to ensure the validity of the sampling process. Sampling of consumers was done randomly in Johannesburg and surrounding areas. Door-to-door recruitment was done where consumers were first screened for shopping role and demographics profile. A screening questionnaire was used to verify the $\operatorname{LSM}^{\circledR}$ segment of the household and other screening criteria. Once qualified, potential consumers were invited to participate by means of one-on-one interviews, at convenient times at their homes. Participants were incentivised. A random sample was back-checked by 'Consumers In Focus' personnel after questionnaires were returned to gauge recruiting accuracy and monitor interview protocol adherence. The meat scandal relating to the presence of foreign meat species in local meat products broke in the media while field work was being performed for the middle-class group. This was taken into consideration when evaluating responses.

Data capturing and cleaning was done in Microsoft Office Excel 2007, after which a wide range of descriptive, comparative analyses (ANOVA (Analysis of Variance) and Chi-square analyses) and multivariate techniques were applied to analyse the data with SPSS (Statistical Package for the Social Sciences) version 21.0.

In addition to the consumer survey, as mentioned above, this paper also reports on a second survey of a different nature involving in-store observational research of fresh red meat products. The second survey was conducted to develop an understanding of the communication of carcass classification information to 
Table 3 Summary of the planned and actual characteristics of the sample in terms of Living Standards Measure $\left(\mathrm{LSM}^{\circledR}\right)$ segment, age category and ethnicity

\begin{tabular}{|c|c|c|c|c|}
\hline Sub-segment: & Variable: & Levels of variable: & $\begin{array}{c}\text { Share of sub- } \\
\text { segment sample: }\end{array}$ & $\begin{array}{c}\text { Share of } \\
\text { population: }\end{array}$ \\
\hline \multirow{9}{*}{$\begin{array}{l}\text { Marginalised } \\
\text { consumers }\end{array}$} & \multirow{3}{*}{ LSM $^{\circledR}$ segment } & $\operatorname{LSM}^{\circledR} 2$ & $9.7 \%$ & $17.5 \%{ }^{1}$ \\
\hline & & $\operatorname{LSM}^{\circledR} 3$ & $26.1 \%$ & $26.7 \%^{1}$ \\
\hline & & $\operatorname{LSM}^{\circledR} 4$ & $64.2 \%$ & $55.7 \%^{1}$ \\
\hline & \multirow{2}{*}{ Age category } & Younger than 35 & $57.3 \%$ & $53.2 \%^{1}$ \\
\hline & & 35 and older & $42.1 \%$ & $46.8 \%^{1}$ \\
\hline & \multirow{4}{*}{ Ethnicity } & Black & $98.8 \%$ & $77.9 \%^{2}$ \\
\hline & & Coloured & $0.6 \%$ & $3.5 \%^{2}$ \\
\hline & & Indian & $0.6 \%$ & $2.9 \%^{2}$ \\
\hline & & White & & $15.7 \%^{2}$ \\
\hline \multirow{10}{*}{$\begin{array}{l}\text { Middle-class } \\
\text { consumers }\end{array}$} & \multirow{4}{*}{ LSM® segment } & $\operatorname{LSM}^{\circledR} 5$ & $17.0 \%$ & $28.6 \%{ }^{1}$ \\
\hline & & $\operatorname{LSM}^{\circledR} 6$ & $38.6 \%$ & $37.9 \%{ }^{1}$ \\
\hline & & $\operatorname{LSM}^{\circledR} 7$ & $22.8 \%$ & $19.2 \%^{1}$ \\
\hline & & LSM $^{\circledR} 8$ & $21.6 \%$ & $14.4 \%^{1}$ \\
\hline & \multirow{2}{*}{ Age category } & Younger than 35 & $42.1 \%$ & $51.2 \%{ }^{1}$ \\
\hline & & 35 and older & $57.9 \%$ & $48.8 \%^{1}$ \\
\hline & \multirow{4}{*}{ Ethnicity } & Black & $75.4 \%$ & $77.9 \%^{2}$ \\
\hline & & Coloured & $9.4 \%$ & $3.5 \%{ }^{2}$ \\
\hline & & Indian & $1.8 \%$ & $2.9 \%^{2}$ \\
\hline & & White & $12.3 \%$ & $15.7 \%^{2}$ \\
\hline \multirow{8}{*}{$\begin{array}{l}\text { Wealthy } \\
\text { consumers }\end{array}$} & \multirow{2}{*}{ LSM $^{\circledR}$ segment } & LSM® 9 & $52.6 \%$ & $60.9 \%^{1}$ \\
\hline & & LSM® 10 & $47.4 \%$ & $39.1 \%^{1}$ \\
\hline & \multirow{2}{*}{ Age category } & $15-24$ & $34.5 \%$ & $43.4 \%^{1}$ \\
\hline & & $25-34$ & $65.5 \%$ & $56.6 \%{ }^{1}$ \\
\hline & \multirow{4}{*}{ Ethnicity } & Black & $27.3 \%$ & $77.9 \%^{2}$ \\
\hline & & Coloured & $4.4 \%$ & $3.5 \%{ }^{2}$ \\
\hline & & Indian & $4.4 \%$ & $2.9 \%^{2}$ \\
\hline & & White & $63.5 \%$ & $15.7 \%^{2}$ \\
\hline
\end{tabular}

${ }^{1}$ Source: SAARF (2013) based on data from SAARF AMPS 2012.

2 Source: Statistics South Africa (2012b) Census 2011 Municipal Report Gauteng. Please note: These values are for Gauteng as a whole and not only for the lower income groups within the province, thus explaining the larger dominance of black consumers in the marginalised consumer sub-segment sample and the dominance of white consumers in the wealthy consumer sample.

consumers by means of fresh red meat product labels. These results were also extracted from a larger research project conducted as an in-store observational product survey with a specific focus on fresh red meat (beef and lamb) labelling claims at major national retailers, chain and independent butcheries, 'factory meat outlets', chain delicatessen ('deli') shops and independent deli shops in selected geographic locations across South Africa, to serve as a sub-sample indicative of what is presented to consumers in South Africa. In September and October 2013 the field work team (final year students at the Department of Consumer Sciences at the University of Pretoria) surveyed a sample of 37 butchers, located in a range of geographical locations in South Africa (e.g. greater Pretoria and Johannesburg areas, Barberton, Bronkhorstspruit, Boksburg, Heidelberg, Hermanus, Kimberley and Secunda). These observations were supplemented with product labelling observations made at large national retail chain outlets. All observations were captured on the survey questionnaire and a Microsoft Office Excel 2007 data capturing sheet. Data analysis involved mainly descriptive statistics. 


\section{Results and Discussion}

In the consumer survey the respondents were asked whether they had knowledge regarding the grading/classification systems of red meat, how often they checked the grading/classification of meat and also to define red meat classification if possible. These questions pertained only to beef and mutton/lamb and not to chicken and pork, as the main focus of the consumer study was on red meat. These results are summarised in Table 4.

The share of respondents within the different sub-samples perceiving that they have knowledge regarding red meat classification differed significantly (Chi-square $=6.536$, $\mathrm{df}=2, P=0.038$ ) with a significantly larger share in the wealthier socio-economic sub-group. Perceived knowledge of beef classification among the middle-class group was generally higher for beef than for mutton/lamb, but it should be kept in mind that beef is also more widely consumed than mutton/lamb. However, it should be noted that even among the wealthy segment only about $15 \%$ of the particular sample perceived that they have red meat classification knowledge. This underlines the inadequacy of consumer knowledge in this regard even among these consumers who have high general education levels.

Table 4 Consumer knowledge and usage of red meat classification as a percentage of various sub-groups

\begin{tabular}{|c|c|c|c|c|}
\hline & & $\begin{array}{l}\text { Marginalised group } \\
\left(\operatorname{LSM}^{\circledR} 1-4\right)(n=165)\end{array}$ & $\begin{array}{l}\text { Middle-class group } \\
\left(\text { LSM }^{\circledR} 5-8\right)(n=171)\end{array}$ & $\begin{array}{c}\text { Wealthy group } \\
\left(\mathrm{LSM}^{\circledR} 9-10\right)(\mathrm{n}=249)\end{array}$ \\
\hline \multicolumn{2}{|c|}{$\begin{array}{l}\text { Share of sample perceiving that have } \\
\text { knowledge regarding red meat } \\
\text { classification }\end{array}$} & $4.2 \%$ (red meat) & $\begin{array}{l}9.9 \% \text { (beef) } \\
5.8 \% \text { (mutton/lamb) }\end{array}$ & $\begin{array}{l}14.9 \% \text { (beef) } \\
12.5 \% \text { (mutton/lamb) }\end{array}$ \\
\hline \multirow{3}{*}{$\begin{array}{l}\text { How often respondents } \\
\text { check the classification } \\
\text { mark when purchasing red } \\
\text { meat }\end{array}$} & & $5.4 \%$ (red meat) & $\begin{array}{l}32.7 \% \text { (beef) } \\
28.1 \% \text { (mutton/lamb) }\end{array}$ & $\begin{array}{l}14.1 \% \text { (beef) } \\
12.6 \% \text { (mutton/lamb) }\end{array}$ \\
\hline & Sometimes & $13.6 \%$ (red meat) & $\begin{array}{l}23.5 \% \text { (beef) } \\
19.9 \% \text { (mutton/lamb) }\end{array}$ & $\begin{array}{l}44.0 \% \text { (beef) } \\
43.9 \% \text { (mutton/lamb) }\end{array}$ \\
\hline & $\begin{array}{l}\text { Always or } \\
\text { Sometimes }\end{array}$ & $19.0 \%$ (red meat) & $\begin{array}{l}56.2 \% \text { (beef) } \\
48.0 \% \text { (mutton/lamb) }\end{array}$ & $\begin{array}{l}58.1 \% \text { (beef) } \\
56.5 \% \text { (mutton/lamb) }\end{array}$ \\
\hline
\end{tabular}

LSM $^{\circledR}$ : Living Standards Measure.

Only $19.0 \%$ of the low $\operatorname{LSM}^{\circledR}$ sample checks the classification mark when buying red meat, increasing significantly towards the middle-class and the wealthy groups to about $50 \%$ and more (Chi-square $=43.828$, $\mathrm{df}=4, P=0.0$ ) despite the fact that few consumers have knowledge regarding red meat classification. An interesting observation relates to the relatively higher share of middle-class consumers who 'always' checks the classification of red meat (about $30 \%$ versus only about $13 \%$ for the wealthy segment). It can be argued that the middle-class group possibly purchases food and meat at retail outlets with potentially lower food safety and quality standards, and thus has to rely more heavily on additional quality cues (such as the classification mark) in their meat choices to reduce the risk of buying potentially unsafe food. On the other hand the wealthy segment probably have significant trust in their selected purchase outlets and consequently pay less attention to other quality cues such as the classification of meat because the potential food safety risk associated with the purchase of meat is 'absorbed' by the trusted retail outlets.

The results presented in Table 5 clearly illustrate that very few consumers could explain red meat classification in terms of animal age and fat class, while most responses related it to be a general indication of product quality.

Only about $4 \%$ of the marginalised segment associate red meat classification with red meat quality, increasing to $8 \%$ of the middle-class group and $11 \%$ of the wealthy group. The ranking of 'grading' among the other concepts mentioned by respondents was 5th for the marginalised- and middle-class groups, and 6th for the wealthy segment. For consumers to willingly purchase and consume a particular food type, they must have positive perceptions about the food. In the context of food and particularly meat, it is normally understood that consumer perception of meat relates to its quality in a broad sense. Even though many respondents did not mention red meat classification directly when defining red meat quality, many aspects potentially related to it qualify such as freshness, meat colour, appearance, smell, tenderness, taste and leanness, were mentioned.

When asked to define red meat safety, a larger share of consumers associated red meat classification with red meat safety than with red meat quality. The shares of the various samples associating red meat 
Table 5 Consumer understanding of red meat classification (open question responses)

\begin{tabular}{|c|c|c|}
\hline $\begin{array}{l}\text { Marginalised group } \\
\left(\operatorname{LSM}^{\circledR} 1 \text { - 4) }\right. \\
\end{array}$ & $\begin{array}{l}\text { Middle-class group } \\
\left(\operatorname{LSM}^{\circledR} 5-8\right) \\
\end{array}$ & $\begin{array}{l}\text { Wealthy group } \\
\left(\operatorname{LSM}^{\circledR} 9-10\right) \\
\end{array}$ \\
\hline \multirow[t]{2}{*}{$\begin{array}{c}\text { Extremely } \\
\text { limited understanding }\end{array}$} & $\begin{array}{l}\text { Beef classification } \\
\text { (16 responses): } \\
\text { - Indication of quality standard/best } \\
\text { quality (60\% of responses) } \\
\text { - } \quad \text { Higher grades more expensive } \\
\text { (12\%) } \\
\text { - Indicated by meat grade stamp } \\
(6 \%)\end{array}$ & $\begin{array}{l}\text { Beef classification } \\
\text { (25 responses): } \\
\text { - } \quad \text { Indication of quality standard/best quality (45\% of } \\
\text { responses). } \\
\text { - } \quad \text { To do with fat on meat (18\%) } \\
\text { - } \quad \text { Different colours for different gradings }(11 \%) \\
\text { - } \quad \text { To do with animal age (11\%) } \\
\text { - } \quad \text { Product certification (8\%) } \\
\text { - } \quad \text { There are A and B grades (6\%) } \\
\text { - } \quad \text { First grade is best (5\%) } \\
\text { - } \quad \text { classification }(3 \%) \\
\text { - } \quad \text { Marbling colour }(3 \%) \\
\quad \text { Purple stamp is the best meat (3\%) }\end{array}$ \\
\hline & $\begin{array}{l}\text { Mutton/lamb classification } \\
\text { (10 responses): } \\
\text { - } \quad \text { Indication of quality standard/best } \\
\text { quality ( } 58 \% \text { of responses) } \\
\text { - } \quad \text { Grade A is best quality }(24 \%) \\
\text { - } \quad \text { Higher grades more expensive } \\
(6 \%) \\
\text { - } \quad \text { Indicated by meat grade stamp } \\
\text { (6\%) } \\
\text { - } \quad \text { First grade best }(6 \%)\end{array}$ & $\begin{array}{ll} & \text { Mutton/lamb classification } \\
\text { (21 responses): } \\
\text { - } \quad \text { Indication of quality standard/best quality (50\% of } \\
\text { - } \quad \text { Thesponses) } \\
\text { - } \quad \text { Different colours for different gradings (6\%) } \\
\text { - } \quad \text { First grade is best }(6 \%) \\
\text { - } \quad \text { To do with fat on meat }(6 \%) \\
\text { - } \quad \text { Green or purple stamp mentioned }(6 \%) \\
\text { - } \quad \text { Ba do with animal age }(6 \% \\
\text { - } \quad \text { Product certification }(3 \%) \\
\text { - } \quad \text { Higher grades more expensive }(3 \%) \\
\text { - } \quad \text { Stamp on meat }(3 \%)\end{array}$ \\
\hline
\end{tabular}

safety with red meat classification were $5 \%$ for the marginalised group, $14 \%$ for the middle-class group and $19 \%$ for the wealthy segment. These results suggest that some consumers associate the classification mark with meat that is safe to eat, which is most probably linked to the 'proper' handling of the meat that is assumed to be associated with classified red meat.

Respondents were asked (in an open-question format) to list their most prominent concerns regarding red meat in general without distinguishing between different grades and cuts. A summary of results is presented in Table 6 . The marginalised group focussed mostly on health (45\%) followed by affordability (40\%) concerns. Interestingly, both the middle-class group and the wealthy consumers focussed mainly on affordability, followed by fattiness and health concerns for both beef and mutton/lamb. Health conscious consumers associate diet with the probability of non-communicable diseases resulting in a shift away from high-fat diets.

Tenderness was a more prominent concern among wealthy beef consumers compared to middle-class beef consumers, and it was not a concern mentioned for mutton/lamb among middle-class and wealthy consumers. It is interesting to observe consumer concerns about fatty meat (middle-class and wealthy groups) and a lack of beef tenderness (wealthy segment) could potentially be improved if they had better knowledge of the red meat classification system which would empower such consumers to make more informed product decisions. From a red meat classification perspective, even though the respondents did not mention red meat classification as a concern, many aspects potentially related to it were identified such as general quality concerns, fatty (also fattiness linked to health concerns), tenderness, meat colour, taste, freshness and smell.

Respondents were asked to define red meat quality in an open-question format. These responses were analysed to determine whether consumers linked the concept of red meat quality with red meat classification (Table 7). Across sub-segments meat colour was an important tangible cue for red meat quality, as well as 'freshness' which seems to be gauged through general product appearance and aspects such as sell-by date. Banovic et al. (2012) confirmed the importance of meat colour as a cue to evaluate beef 
Table 6 Dominant consumer concerns regarding red meat (open-question responses)* as a percentage of sub-groups

\begin{tabular}{|c|c|c|c|c|}
\hline \multirow{2}{*}{$\begin{array}{l}\text { Marginalised group } \\
\left(\operatorname{LSM}^{\circledR} 1 \text { - 4) }\right.\end{array}$} & \multicolumn{2}{|c|}{ Middle-class group (LSM ${ }^{\circledR} 5$ - 8) } & \multicolumn{2}{|c|}{ Wealthy group (LSM $\left.{ }^{\circledR} 9-10\right)$} \\
\hline & Beef concerns & Mutton/lamb concerns & Beef concerns & $\begin{array}{c}\text { Mutton/lamb } \\
\text { concerns }\end{array}$ \\
\hline $\begin{array}{l}\text { - Health concerns } \\
(45.4 \%) \\
\text { - (e.g. fatty, cholesterol, } \\
\text { blood pressure, heart } \\
\text { problems, diabetes, } \\
\text { allergies, gout) } \\
\text { - Affordability (40.2\%) } \\
\text { - Long cooking time } \\
(2.1 \%) \\
\text { - Availability (1.0\%) } \\
\text { - General quality } \\
\text { concerns }(1.0 \%) \\
\text { - 'Mixed with strange } \\
\text { meat' (1.0\%) } \\
\text { - Perishable }(1.0 \%)\end{array}$ & $\begin{aligned} & \text { - } \text { Affordability } \\
&(17.5 \%) \\
& \text { - Fatty }(5.8 \%) \\
& \text { - Health concerns } \\
&\text { ( } 7.0 \%) \\
& \text { - Long cooking time } \\
& \text { (4.7\%) } \\
& \text { - Dark colour }(2.3 \%) \\
& \text { - Not tender }(1.8 \%) \\
& \text { - Perishability }(1.8 \%)\end{aligned}$ & $\begin{array}{l}\text { - Affordability } \\
(24.0 \%) \\
\text { - Fatty }(11.7 \%) \\
\text { - Health concerns } \\
\text { (4.0\%) } \\
\text { - Dark colour }(1.2 \%) \\
\text { - Long cooking time } \\
\text { (0.6\%) } \\
\text { - Not tender }(0.6 \%)\end{array}$ & $\begin{array}{l}\text { - Affordability } \\
(35.7 \%) \\
\text { - Fatty }(28.5 \%) \\
\text { - Not tender }(13.7 \%) \\
\text { - Quality concerns } \\
\text { (9.6\%) } \\
\text { - Freshness }(7.6 \%) \\
\text { - Long cooking time } \\
\text { (5.2\%) } \\
\text { - Health concerns } \\
\text { (2.4\%) }\end{array}$ & $\begin{array}{l}\text { - Affordability } \\
\text { (55.2\%) } \\
\text { - Fatty }(37.1 \%) \\
\text { - Bad taste }(6.0 \%) \\
\text { - Quality concerns } \\
\text { (5.6\%) } \\
\text { - Colour (5.2\%) } \\
\text { - Health concerns } \\
\text { (4.0\%) }\end{array}$ \\
\hline
\end{tabular}

*NOTE: the aspects mentioned by the respondents with links to red meat classification are highlighted in grey.

LSM $^{\circledR}$ : Living Standards Measure.

quality. Interestingly, wealthy consumers also associated quality red meat with lean meat. Appearance determines how consumers perceive quality and significantly influences purchasing behaviour. The amount of visible fat is a strong visual cue for consumers. Fat is perceived as negative, as are all aspects associated with fat. Brewer et al. (2001) found that highly marbled chops appeared lighter coloured, less lean, had a less acceptable appearance and were less likely to be purchased. Carpenter et al. (2001) showed that consumer preference for beef colour was sufficient to influence their likelihood to purchase, but was not enough to bias eating satisfaction at home. Nevertheless, the presentation of fresh red meats with appropriate colour at retail level is of the utmost importance as consumers will discriminate negatively against meat that does not appear to match their expectations.

Flavour, juiciness and succulence together with tenderness are important factors in meat palatability. Marginalised- and middle-class consumers did not mention tenderness as associated with red meat quality, while only $10.8 \%$ of the wealthy segment did make this association. This was not expected as it was anticipated that the association between red meat quality and tenderness would be much stronger.

Table 7 Dominant consumer associations with red meat quality (defining red meat quality in an openquestion format)* as a percentage of sub-groups

\begin{tabular}{|c|c|c|}
\hline $\begin{array}{l}\text { Marginalised group } \\
\left(\operatorname{LSM}^{\circledR} 1-4\right)(n=165)\end{array}$ & $\begin{array}{l}\text { Middle-class group } \\
\left(\operatorname{LSM}^{\circledR} 5-8\right)(n=171)\end{array}$ & $\begin{array}{l}\text { Wealthy group } \\
\left(\text { LSM }^{\circledR} \text { 9-10) }(n=249)\right.\end{array}$ \\
\hline $\begin{array}{ll}\text { - } & \text { Freshness }(40.0 \%) \\
\text { - } & \text { Meat colour red }(21.2 \%) \\
\text { - } & \text { Clean meat }(12.1 \%) \\
\text { - } & \text { Appearance }(4.8 \%) \\
\text { - } & \text { Grading }(4.2 \%) \\
\text { - } & \text { Price }(3.0 \%) \\
\text { - } & \text { Nutritional value }(1.8 \%) \\
\text { - } & \text { Shelf life }(1.8 \%) \\
\text { - } & \text { Smell }(1.8 \%) \\
\text { - } & \text { Tenderness, taste }(1.8 \%)\end{array}$ & $\begin{array}{ll}\text { - } & \text { Meat colour }(25.1 \%) \\
\text { - } & \text { Freshness }(21.1 \%) \\
\text { - } & \text { Appearance }(19.3 \%) \\
\text { - } & \text { Clean meat }(11.1 \%) \\
\text { - } & \text { Grading }(8.2 \%) \\
\text { - } & \text { Smell }(8.2 \%)\end{array}$ & $\begin{array}{ll}\text { - } & \text { Colour red/pink/uniform (40.2\%) } \\
\text { - } & \text { Freshness }(27.3 \%) \\
\text { - } & \text { Leanness }(16.1 \%) \\
\text { - } & \text { Smell is good }(14.1 \%) \\
\text { - } & \text { Clean }(10.8 \%) \\
\text { - } & \text { Grading }(10.8 \%) \\
\text { - } & \text { Tenderness }(10.8 \%) \\
\text { - } & \text { Appearance }(9.2 \%) \\
\text { - } & \text { Good cut }(7.2 \%) \\
\text { - } & \text { Taste }(6.0 \%)\end{array}$ \\
\hline
\end{tabular}

*NOTE: the aspects mentioned by the respondents with links to red meat classification are highlighted in grey. $\mathrm{LSM}^{\circledR}$ : Living Standards Measure. 
Consumer purchase considerations for raw beef and raw mutton/lamb were also investigated. Tables 8 and 9 present the ranking of consumer purchase consideration attributes for beef and mutton/lamb comparing the three socio-economic sub-segments.

The dominant purchase considerations for both beef and mutton/lamb focussed largely on safety, appearance, price and eating quality. Price was significantly more important among the poor- and middleclass groups for both beef and mutton/lamb, while expiry date was significantly more important among the middle-class and wealthy groups. Similarly, Du Plessis \& Du Rand (2012) found that when purchasing lamb, South African consumers predominantly considered price, followed by food safety and quality. In a rural South African setting Vimiso et al. (2012) also confirmed consumer reliance on price and visual cues to develop quality perceptions of meat. It could be argued that the type of red meat purchased by poor consumers may not even have an expiry date on the packaging or that they lack understanding of the concept of sell-by dates. Food safety and clean meat (without blood) were important to all sub-segments.

The attribute 'Grading stamp' (indicative of red meat classification) was not among the top 20 considerations for consumers even though many aspects potentially related to red meat classification appeared in the top 20 such as appearance, quality, tenderness and fat-related attributes.

To compare consumer preferences with the actual information on classification presented to South African consumers on red meat product labels, this section presents an overview of the results from in-store observational research at retail outlets (independent butchers and national chain retailers) selling fresh red meat. The fresh red meat labelling claims observed at independent butchers are shown in Table 10. Product pricing information (price per kilogram and price per packet), store branding and meat cut information appeared on labels at all the sampled independent butchers, while $92 \%$ of these butchers indicated the packaging date on labels. The next cluster of labelling information aspects appeared on the fresh red meat labels of $22 \%$ to $43 \%$ of the sampled butchers and included the following: Distinguishing between mutton and lamb, a unique product brand, sell-by date, flavour added to meat (e.g. marinade, spices), home storage

Table 8 The top 20 considerations (in order of importance) for the various socio-economic sub-groups when purchasing raw beef (marginalised group) and beef steak (middle-class and wealthy groups)*

\begin{tabular}{|c|c|c|}
\hline $\begin{array}{l}\text { Marginalised group } \\
\left.\text { (LSM }^{\circledast} 1-4\right)(n=165)\end{array}$ & $\begin{array}{l}\text { Middle-class group } \\
\left(\text { LSM }^{\circledR} 5-8\right)(\mathrm{n}=171)\end{array}$ & $\begin{array}{l}\text { Wealthy group } \\
\left(\operatorname{LSM}^{\otimes} 9-10\right)(n=249)\end{array}$ \\
\hline Price & Expiry date & Food safety \\
\hline Appearance & Price & Expiry date \\
\hline Cleanliness & Meat colour & Quality guarantee \\
\hline Meat colour & Appearance & Taste \\
\hline Quality guarantee & Clean meat & Appearance \\
\hline Convenience & Food safety & Meat colour \\
\hline Tenderness & Taste & Clean meat \\
\hline Expiry date & Quality guarantee & Flavour \\
\hline Bone-to-meat-ratio & Easy to prepare & Visual appeal \\
\hline Eaten by all & Flavour & Price \\
\hline Easy to prepare & Tenderness & Tenderness \\
\hline Fat-to-meat-ratio & Eaten by all in family & Eaten by all in family \\
\hline Packaging size & Fat-to-meat-ratio & Store where you buy \\
\hline Fat colour & Freshness & Keepability \\
\hline Preparation time & Store where you buy meat & Nutritional value \\
\hline Freshness & Visual appeal & Succulence \\
\hline Taste & Brand/Product reputation & Fat-to-meat-ratio \\
\hline Juiciness & Packaging size & Household preferences \\
\hline Packaging type & Preparation time & Fresh (not frozen) meat \\
\hline Flavour & Convenience & Brand/product reputation \\
\hline
\end{tabular}

${ }^{*}$ NOTE: the aspects mentioned by the respondents with potential links to red meat classification are highlighted in grey. $\mathrm{LSM}^{\circledR}$ : Living Standards Measure. 
instructions, 'Tender' and 'Quality'/'Quality guaranteed'. Other labelling information mentioned in Table 8 as applicable to less than $20 \%$ of the sampled butchers, included aspects such as country of origin, expiry date, cooking recommendations, additives added to meat (e.g. MSG, salt, $\mathrm{SO}_{2}$ ), 'Lean'/'Extra lean', cooking instructions, recipe, 'Tasty', 'Aged'/'Matured', cooking time, region of origin, 'Fresh', claims indicating specials or value-for-money, red meat classification (animal age and fat class), fat-to-meat ratio, 'Juicy', 'Grain-fed' and allergens listed on label. Thus, the bulk of fresh red meat sold at the observed butchers was more 'generic' with mainly the price and meat cut (and packaging date in many cases) indicated on the product packaging.

Even though the labelling of fresh red meat at some of the national retailers is more sophisticated than at most butchers, a large share of the fresh red meat sold at national retailers is 'generic' with only the store brand, price, meat cut and sell-by date indicated on the product packaging. Labelling information with additional but limited application among the national retail outlets included the following: Claims indicating specials or value-for-money, unique product brand, classification information related to animal age ('A-grade') other date information (e.g. use-by date), 'Lean'/'Extra lean', 'Low fat', 'Tender', 'Tasty', 'Juicy', storage instructions at home, cooking suggestions, serving suggestions, 'Aged'/'Matured', 'Deboned' and flavour added (e.g. marinade, spices).

It is evident that observations related to fresh red meat classification were insignificant (applicable to fewer than $5 \%$ of butchers). Selected brands offered by large retailers indicated more advanced labelling information (such as free range, region of origin, feeding practices, animal welfare), but extremely limited labelling information regarding red meat classification was observed with only limited observations of terms such as 'A-grade' indicated on some more up-market red meat cuts. Further investigation is needed to determine whether the limited application of labelling claims is related to a lack of product innovation in the

Table 9 The top 20 considerations (in order of importance) for different socio-economic sub-groups when purchasing raw mutton/lamb (marginalised group) and mutton/lamb chops (middle-class- and wealthy groups)*

\begin{tabular}{|c|c|c|}
\hline $\begin{array}{l}\text { Marginalised group } \\
\left(\operatorname{LSM}^{\circledR} 1-4\right)(n=165)\end{array}$ & $\begin{array}{l}\text { Middle-class group } \\
\left(\text { LSM }^{\circledR} 5-8\right)(n=171)\end{array}$ & $\begin{array}{l}\text { Wealthy group } \\
\left(\text { LSM }^{\circledR} \text { 9-10) }(n=249)\right.\end{array}$ \\
\hline Price & Price & Food safety \\
\hline Meat colour & Appearance & Expiry date \\
\hline Appearance & Expiry date & Taste \\
\hline Easy to prepare & Taste & Meat colour \\
\hline Clean meat (e.g. no blood) & Food safety & Appearance \\
\hline Tenderness & Flavour & Flavour \\
\hline Amount of meat per package & Meat colour & Price \\
\hline Quality guarantee & Clean meat & Clean meat \\
\hline Bone-to-meat ratio & Quality guarantee & Visual appeal \\
\hline Expiry date & Juiciness & Tenderness \\
\hline Convenience & Store where you buy meat & Quality guarantee \\
\hline Fat colour & Easy to prepare & Eaten by all in family \\
\hline Fat-to-meat-ratio & Tenderness & Amount of fat \\
\hline Packaging size & Eaten by all in family & Keepability \\
\hline Fresh (not frozen) & Amount of fat & Juiciness \\
\hline Eaten by all in family & Freshness & Nutritional value \\
\hline Juiciness & Lean/low fat meat & Store where you buy meat \\
\hline Taste & Brand Product Reputation & Natural \\
\hline Preparation time & Packaging size & Freshness \\
\hline Packaging & Convenience & Personal preferences \\
\hline
\end{tabular}

*NOTE: the aspects mentioned by the respondents with potential links to red meat classification are highlighted in grey. LSM $^{\circledR}$ : Living Standards Measure. 
industry or whether retailers do not wish to make statements on their product labels which may be viewed as contentious of the recently updated Food Labelling Regulations (R429, of 29 May 2014).

Table 10 Summary of fresh red meat labelling claims observed at independent butchers

\begin{tabular}{|c|c|c|}
\hline Claim: & Claim category: & $\begin{array}{l}\text { Share of } \\
\text { butchers } \\
(n=37) \text { : }\end{array}$ \\
\hline Price per kg; Price per package & Product pricing & $100 \%$ \\
\hline Store brand & Branding & $100 \%$ \\
\hline Meat cut & Cut & $100 \%$ \\
\hline Packaging date & Date information & $92 \%$ \\
\hline Distinguishing between mutton and lamb & Classification (only applicable to mutton/lamb) & $43 \%$ \\
\hline Unique product brand & Branding & $32 \%$ \\
\hline Sell-by date & Date information & $32 \%$ \\
\hline Home storage instructions & Post-purchase handling & $24 \%$ \\
\hline ‘Tender' & Palatability claims & $22 \%$ \\
\hline ‘Quality’QQuality guaranteed & Quality & $22 \%$ \\
\hline Flavour added (e.g. marinade, spices) & Palatability claims & $30 \%$ \\
\hline Country of origin & Origin & $16 \%$ \\
\hline Expiry date & Date information & $14 \%$ \\
\hline Cooking recommendations & Post-purchase handling instructions & $14 \%$ \\
\hline $\begin{array}{l}\text { Additives such as MSG, salt, } \mathrm{SO}_{2} \text { listed on } \\
\text { packaging }\end{array}$ & Additives & $14 \%$ \\
\hline Lean (mince) & Fat related claims & $11 \%$ \\
\hline Cooking instructions/recipe & Post-purchase handling & $11 \%$ \\
\hline ‘Tasty’ & Palatability claims & $8 \%$ \\
\hline Aged/matured & Post-slaughter handling & $8 \%$ \\
\hline Cooking time & Post-purchase handling & $\leq 5 \%$ \\
\hline Region of origin & Origin & $\leq 5 \%$ \\
\hline ‘Fresh’ & Palatability claims & $\leq 5 \%$ \\
\hline Claims indicating specials or value-for-money & Affordability & $\leq 5 \%$ \\
\hline Classification (animal age and fat class) & Classification & $\leq 5 \%$ \\
\hline Fat-to-meat ratio & Fat related claims & $\leq 5 \%$ \\
\hline 'Juicy' & Palatability claims & $\leq 5 \%$ \\
\hline Grain-fed beef & Production practices & $\leq 5 \%$ \\
\hline Allergens listed on label & Allergens & $\leq 5 \%$ \\
\hline
\end{tabular}

\section{Conclusions and Recommendations}

The poor consumer segment had very limited understanding and gave little attention to red meat classification. Although middle-class and wealthy consumers also had a limited understanding of red meat classification, about half of the sampled consumers checked the red meat classification sometimes or often when buying beef or mutton/lamb.

Among red meat problems or concerns perceived by consumers, red meat classification was not prominent. However, many aspects potentially related to classification were of concern such as general quality concerns, fattiness (also fattiness linked to health concerns), tenderness, meat colour, taste, freshness and smell.

Many respondents did not mention red meat classification when defining red meat quality and safety, but many aspects potentially related to classification were mentioned such as freshness, meat colour, appearance, smell, tenderness, taste and leanness. There was little association between red meat grading 
and red meat quality and safety. Only $5 \%$ of the low LSM $^{\circledR}$ sample associated grading with red meat quality and safety. Among the middle-class and wealthy consumers up to $11 \%$ of consumers associated red meat classification with quality and up to $19 \%$ of consumers associated it with safety. These associations were stronger among the higher LSM $^{\circledR}$ consumers. Thus, the results indicated a slightly stronger association between red meat grading and safety compared to quality.

Among an extensive range of red meat decision factors, red meat classification was not among the top 20 most important factors. Once again, many aspects potentially related to red meat classification were important such as appearance, taste, flavour, quality guarantee, meat colour, fat content, juiciness and tenderness. It is interesting to note that the place of purchase is a stronger quality cue to consumers than the classification marks on the meat. This is an important observation and could be further investigated in future.

There is a definite need for comprehensive consumer education about the red meat classification system and its implications in terms of product characteristics and quality. The pork industry in the United States of America (USA) has portrayed pork as a light and nutritious alternative to chicken with the 'Pork: the other white meat' advertising campaign launched in 1997 which focussed on leaner cuts with a lower fat content. Research indicates that consumers are now less likely to perceive pork negatively in terms of fat (Resurreccion, 2003). Enhanced knowledge could assist consumers to make more informed decisions and to utilise the red meat carcass classification system as a useful tool. However, given the potential loss of product identity which occurs at the point in the supply chain where carcasses are processed into individual meat cuts, it is critical that fresh red meat product labels should have trustworthy and clear indications of the class of the meat being sold. This research illustrated that the current application of classification information displayed on fresh red meat labels is extremely limited. There is a definite need for the development and consumer testing of an appropriate front-of-pack labelling system to communicate red meat classification to consumer by means of product labels.

\section{Acknowledgements}

The authors would like to acknowledge the support from the Red Meat Research and Development South Africa (RMRDSA), and the Institute of Food, Nutrition and Well-being, University of Pretoria, for funding the research presented in this paper.

\section{References}

Banovic, M., Fontes, M.A., Barreira, M.M. \& Grunert, K.G., 2012. Impact of product familiarity on beef quality perception. Agribusiness 28 (2), 157-172.

Brewer, M.S., Zhu, L.G. \& McKeith, F.K., 2001. Marbling effects on quality characteristics of pork loin chops: consumer purchase intent, visual and sensory characteristics. Meat Sci. 59, 153-163.

Bureau for Food and Agricultural Policy (BFAP), 2014. BFAP Baseline Agricultural Outlook 2014-2023. August 2014. Pretoria, South Africa. pp. 90-109.

Carpenter, C.E., Cornforth, D.P. \& Whittier, D., 2001. Consumer preferences for beef color and packaging did not affect eating satisfaction. Meat Sci. 57, 359-363.

City of Johannesburg, 2013. Quick facts about Gauteng Province, viewed 22 July 2014, <www.joburg.org.za/index.php?option=com_content\&id=399\&Itemid=52\#ixzz2PtqizwkY>

De Cock, N., D'Haese, M., Vink, N., Van Rooyen, C.J., Staelens, L., Schönfeldt, H.C. \& D'Haese, L., 2013. Food security in rural areas of Limpopo Province, South Africa. Food Secur. 5, 269-282.

Department of Agriculture, 1990. Agricultural Product Standards Act (Act No.119 of 1990), DAFF, Pretoria.

Du Plessis, H. \& Du Rand, G., 2012. Food traceability in the context of Karoo lamb: supply chain and consumer perspectives. Int. J. Consum. Stud. 36, 401-407.

Healthy Meat South Africa, 2012. Carcass Classification Leaflet, viewed 20 July 2014 , <http://www.healthymeat.co.za/Resources/tabid/1393/id/710/Default.aspx>

Kotler, P., 2000. Marketing management. Prentice Hall International, New Jersey. pp. 57.

Oude Ophuis, P.A.M. \& Van Trijp, H.C.M., 1995. Perceived quality: a market driven and consumer orientated approach. Food Qual. Prefer. 6, 177-183.

Resurreccion, A.V.A., 2003. Sensory aspects of consumer choices for meat and meat products. Meat Sci. 66, 11-20.

South African Audience Research Foundation (SAARF), 2013. SAARF trends, 2008-2012, Based on data from SAARF AMPS. Bryanston, South African. pp. 92-96.

South African Pork Producers' Organisation (SAPPO), 2000. Project Babe. Prepared for the SA Pork Producers' Organisation by AC Nielsen, MRA. June 2000.

Statistics South Africa, 2008. Income and expenditure of households: 2005/2006. Statistical release P0100. Viewed 22 July 2014, <www.statssa.gov.za/publications/statsdownload.asp?PPN=P0100\&SCH=4108> 
Statistics South Africa, 2012a. Income and expenditure of households: 2010/2011. Statistical release P0100. Viewed 22 July 2014, $<$ www.statssa.gov.za/publications/statsdownload.asp?PPN=P0100\&SCH=5371>

Statistics South Africa, 2012b. Census 2011: Municipal report, Gauteng. Report number 03-01-55. Viewed 30 June 2014. <http://www.statssa.gov.za/Census2011/Products/GP_Municipal_Report.pdf>

Steenkamp, J.-B.E.M., 1989. Product Quality. Van Gorcum, Assen, The Netherlands.

The Meat Board, 1996. Quantitative survey. Prepared for The Meat Board and Grey Advertising by Market Research Africa. July 1996.

The Meat Board, 1996. Protein survey. Multibus. Prepared for Grey Advertising and The Meat Board by Market Research Africa. August 1996.

The Meat Board, 1997. Quantitative survey. Prepared for The Meat Board and Grey Advertising by Market Research Africa. August 1997.

Vimiso, P., Muchenje, V., Marume, U. \& Chiruka, R., 2012. Preliminary study on consumers' and meat traders' perceptions of beef quality and how the beef quality is affected by animal welfare practices. Sci. Res. Essays 7 (22), 2037-2048. 